\title{
АДМІНІСТРАТИВНО-ПРАВОВИЙ СТАТУС ЮВЕНАЛЬНОГО ПОЛІЦЕЙСЬКОГО: ПИТАННЯ СЬОГОДЕННЯ
}

Зеленський $\epsilon$. С.

У науковій статті досліджено адміністративно-правовий статус ювенального поліцейського відповідно до норм чинного законодавства, під яким розуміють регламентовану нормативно-правовими актами України сукупність прав та обов'язків щодо запобігання вчиненню дітьми та щодо дітей кримінальних і адміністративних правопорушень, виявлення причин і умов, які цьому сприяють, вжиття в межах своєї компетенції заходів для їх усунення, а також юридичну відповідальність у разі невиконання покладених обов'язків. Автор акцентує увагу на компетенції ювенального поліцейського. У висновку запропоновано напрями вдосконалення адміністративно-правового статусу ювенального поліцейського.

Ключові слова: адміністративно-правовий статус, компетенція, повноваження, відповідальність, ювенальний поліцейський.

В научной статье исследован административно-правовой статус ювенального полицейского в соответствии с нормами действующего законодательства, под которым понимают регламентированную нормативно-правовыми актами Украины совокупность прав и обязанностей по предотвращению совершения детьми и в отношении детей уголовных и административных правонарушений, выявление причин и условий, которые этому способствуют, принятие в пределах своей компетенции мер по их устранению, а также юридическую ответственность в случае невыполнения возложенных обязанностей. Автор акцентирует внимание на компетенции ювенального полицейского. В заключении предложены направления совершенствования административно-правового статуса ювенального полицейского.

Ключевые слова: административно-правовой статус, компетенция, полномочия, ответственность, ювенальный полицейский.

In the scientific article the administrative and legal status of a juvenile policeman is examined in accordance with the norms of the current legislation. We suggest under administrative and legal status of juvenile policeman to understand regulated the normatively-legal acts of Ukraine totality of rights and duties in relation to prevention of feasance children and in relation to the children of criminal and administrative offences, exposure of reasons and terms that it is assisted, use within the limits of the competence of events for their removal, and also legal responsibility in case of non-fulfillment of the fixed duties.

The author focuses on the competence of juvenile policeman. The conclusion suggests directions for improving the administrative and legal status of juvenile policeman:

- addition professional and qualifying requirements to juvenile policemen by a desirable presence together with legal yet pedagogical or psychological education (to the profession);

- addition of plenary powers of juvenile policeman by an operative and criminal investigation function that in particular will assist realization of task in relation to setting of location of child in case of her obscure disappearance, and criminal and judicial that is actually executed during bringing in of juvenile policeman to participating in pre-trial investigation and during $a$ judicial trial with participation of children; a reformatting of realization of project is the "School officer of police" by bringing in of patrol not policemen the professionally-qualifying requirements of that do not answer the allotted plenary powers, but juvenile policeman, what directly authorized agents and specialized on application of preventive events in relation to children;

addition of plenary powers of juvenile policeman registering of adult persons that accomplished administrative or criminal crimes in relation to a child.

Key words: administrative and legal status, competence, powers, responsibility, juvenile policeman.

Постановка проблеми та іï актуальність. Ювенальні поліцейські - це ті посадові особи Національної поліції України, які безпосередньо займаються питаннями профілактики вчинення кримінальних та адміністративних правопорушень дітьми та щодо дітей. Тобто фактично інші служби у разі потреби спілкування з дітьми звертаються до ювенального поліцейського, який має такий досвід і спеціалізується на цьому. Тому важливість визначення чіткої компетенції ювенальних поліцейських з метою відмежування завдань ы функцій інших підрозділів Національної поліції України продовжує бути актуальною в умовах реформування органів ы підрозділів МВС України.

Тим більше набуває актуальності дослідження адміністративно-правового статусу ювенального поліцейського з огляду на змінну історичну структурну підпорядкованість підрозділів ювенальної превенції (кримінальної міліції у справах дітей, кримінальної міліції у справах неповнолітніх тощо) блоку кримінальної міліції або превентивної діяльності (міліції громадської безпеки). Дискусії щодо компетенції ювенального поліцейського тривають і дотепер.

Аналіз останніх досліджень і публікацій. Так, основою написання даної наукової роботи стали доробки вітчизняних вчених, які досліджували діяльність підрозділів ювенальної превенції. Безпосередньо питання профілактики правопорушень серед неповнолітніх були предметом дослідження С.Г. Поволоцької та Я.М. Квітки; зміст адміністративної відповідальності неповнолітніх, батьків або осіб, які їх замінюють, досліджували О.В. Горбач, Ю.І. Ковальчук, О.Л. Чернецький; адміністративно-правові заходи протидії правопорушенням, вчиненим неповнолітніми, у сфері незаконного обігу наркотичних засобів, психотропних речовин і прекурсорів дослідив М.П. Легецький; адміністративно-правове забезпечення прав і свобод неповнолітніх вивчала Т.Г. Корж-Ікаєва. Узагальнене дослідження адміністративно-правової діяльності органів і служб у справах дітей щодо профілактики правопорушень провела Н.В. Лесько, яка продовжує дослідження тематики і цього року виходить на захист дисертації «Адміністративно-правове забезпечення формування та реалізації державної полі- 
тики у сфері захисту дітей від насильства та інших протиправних дій» на здобуття наукового ступеня доктора юридичних наук. Спробою комплексного дослідження адміністративно-правових засад правоохоронної діяльності кримінальної міліції у справах дітей є дисертаційне дослідження О.В. Нікітенко.

Однак, питання адміністративно-правового статус ювенального поліцейського в адміністративно-правовій науці досліджені фрагментарно, що в умовах сьогодення потребує більш детальної розробки та удосконалення.

Метою статті $\epsilon$ дослідження змісту адміністративно-правового статусу ювенального поліцейського в умовах чинного законодавства.

Виклад основного матеріалу. Адміністративно-правовий статус поліцейського в Україні регламентований нормами Закону України «Про Національну поліцію» [1] і в цілому визначає компетенцію та відповідальність кожного поліцейського. Безпосередньо адміністративно-правовий статус ювенального поліцейського деталізовано в Інструкції з організації роботи підрозділів ювенальної превенції Національної поліції України, яка затверджена наказом МВС України від 19.12.2017 № 1044 [2].

Традиційно зміст адміністративно-правового статусу визначається через його структурні елементи: права, обов'язки, юридична відповідальність (Ю.П. Битяк, І.П. Голосніченко, В. М. Горшенев, В. В. Зуй та інші [3-6]).

Проведене нами дослідження прав та обов'язків (повноважень) ювенального поліцейського дозволяє зробити наступні висновки.

Особливий об'єкт діяльності ювенального поліцейського - дитина, тобто особа до досягнення нею повноліття (18 років) (ст. 6 Сімейного кодексу України [7]). Така обставина вимагає від ювенальних поліцейських додаткових знань, умінь та навичок спілкування з дітьми різних вікових категорій, які опинилися у складних життєвих обставинах. Крім того, з метою якісного виконання покладених обов'язків ювенальні поліцейські потребують знань щодо способу життя, інтересів, кола та прийомів спілкування дітей, тощо. Тобто, обставин, які можуть впливати на поведінку дитини, яка опинилася або може опинитися у складних життєвих обставинах.

Особливість діяльності ювенального поліцейського також становить знання та застосування вітчизняного законодавства, яке гарантує дотримання прав, свобод та інтересів дитини відповідно до міжнародних стандартів. Таке законодавство дещо відрізняється від законодавства, застосовуваного до повнолітніх осіб. Наприклад, опитування дітей відбувається тільки за участю батьків (одного з них), іншого законного представника або педагога (ст. 33 Закону України «Про Національну поліцію»), а допит - у присутності законного представника, педагога або психолога, а за необхідності - лікаря (ст. 226 КПК). Також відповідно вимог ст. 43 Закону України «Про Національну поліцію» «Порядок застосування поліцейського примусу» заборонено застосування фізичної сили, спеціальних засобів і вогнепальної зброї до малолітніх осіб, крім випадків учинення ними збройного чи групового нападу, учинення збройного опору поліцейському, що загрожує життю і здоров'ю інших осіб або поліцейських, якщо відбити такий напад або опір іншими способами і засобами неможливо.

Усе це дає змогу зробити висновок про необхідність введення додаткових професійно-кваліфікаційних вимог до посади ювенального поліцейського, які дозволять кваліфіковано реалізувати поставлені перед такою посадовою особою завдання. Серед таких вимог може бути наявність педагогічної або психологічної освіти ювенального поліцейського.

Продовжуючи досліджувати повноваження ювенального поліцейського, ми з'ясували, що переважна більшість повноважень, якими наділений ювенальний поліцейський, є превентивними, тобто діяльність такого поліцейського акцентована на попередження кримінальних та адміністративних правопорушень, вчинених дітьми та щодо дітей.

Водночас відомчий наказ визначає одним із основних повноважень ювенального поліцейського $\epsilon$ участь у судовому розгляді за участю неповнолітнього обвинуваченого відповідно до статей 496, 500 Кримінального процесуального кодексу України [2]. Крім того, ювенального інспектора фактично залучають до участі в досудовому розслідуванні кримінальних справ за участю дітей супроводження кримінальних справ за участю дитини. Такі повноваження реалізують кримінально-процесуальну функцію Національної поліції та виходять за межі задекларованої в законодавстві превентивної спрямованості підрозділів ювенальної превенції.

Доповнюючи сказане, треба зазначити, що основним завданням для ювенальних поліцейських, крім іншого, $\epsilon$ участь в установленні місцезнаходження дитини в разі ii безвісного зникнення чи отриманні даних для цього в межах кримінального провадження, відкритого за фактом їі безвісного зникнення [2]. Установлення місцезнаходження дитини, яка зникла безвісті, як правило, відбувається шляхом реалізації оперативно-розшукових заходів, застосовувати які ювенальні поліцейські не мають права згідно чинного законодавства. Вбачаємо, що доповнення оперативно-розшуковою функцією повноважень ювенального поліцейського сприятиме більш ефективному та оперативному виконанню названого завдання.

I ще раз хотілося 6 акцентувати увагу на превентивній складовій повноважень ювенального поліцейського, які уповноважені здійснювати як загальну, так і індивідуальну профілактику. Водночас, в останні роки керівництвом Національної поліції та МОН продовжує реалізовуватися проект «Шкільний офіцер поліції», який має на меті сприяння діяльності навчальних закладів щодо профілактики правопорушень серед дітей та забезпечення безпечного навчального середовища. Для зазначеної діяльності біли відібрані працівники патрульної поліції, які пройшли тренінг та реалізують проект. Заняття відбуваються у формі гри для молодших класів та групової практичної роботи для середніх та старших класів. Окремим напрямком роботи шкільних офіцерів $\epsilon$ налагодження взаємодії з батьками.

3 вище сказаного виникає питання: чому до проекту «Шкільний офіцер поліції» залучать патрульних поліцейських, а не ювенальних поліцейських? Таке рішення зовсім не співпадає з основним призначення підрозділів патрульної поліції та професійно-кваліфікаційними вимогами, які ставляться до інспекторів патрульної поліції. Під час виконання таких повноважень особливо важлива наявність освіти педагога або психолога у поліцейського, який проводить зазначені заняття з дітьми, що найчастіше зустрічається у фахових підрозділах - підрозділах ювенальної превенції. Тому ми пропонуємо на посади шкільних офіцерів поліції призначати ювенальних поліцейських, що кореспондується із завданнями, які стоять перед підрозділом, а також 
реалізацією принципу реформування МВС України уникнення дублювання повноважень в органах та підрозділах Національної поліції України.

Ще одним удосконаленням адміністративно-правового статусу ювенального поліцейського вважаємо необхідність проведення ними профілактичної роботи не тільки з дітьми, які вчинили кримінальне або адміністративне правопорушення, а й з дорослими особами, які вчинили такі правопорушення щодо дитини. Так, відповідно до Інструкції з організації роботи підрозділів ювенальної превенції Національної поліції України ювенальні поліцейські ведуть профілактичні обліки дітей, які засуджені судом до покарання, не пов'язаного з позбавленням волі; звільнених за рішенням суду від кримінальної відповідальності із застосуванням примусових заходів виховного характеру без поміщення до школи або професійного училища соціальної реабілітації для дітей, які потребують особливих умов виховання; яким оголошено повідомлення про підозру в учиненні кримінального правопорушення; звільнених зі спеціальної виховної установи; які не досягли 18 років і вчинили домашнє насильство у будь-якій формі (дитина-кривдник); які впродовж року два і більше разів були притягнуті до адміністративної відповідальності; які впродовж року два і більше разів самовільно залишали сім'ю, навчально-виховний заклад чи спеціальну установу для дітей [2].

Звісно, превентивний облік повнолітніх осіб прерогатива дільничних офіцерів поліції [8]. Проте, якщо об'єкт посягання таких осіб - дитина, ювенальний поліцейський має володіти інформацією з метою недопущення в подальшому вчинення протиправних дій щодо дітей. На наш погляд, саме ведення обліку повнолітніх осіб, які вчинили домашнє насильство щодо дитини; які вчинили кримінальне правопорушення щодо дитини; які вчинили впродовж року два і більше адміністративних правопорушень щодо дитини, сприятиме ефективному та оперативному виконанню обов'язків ювенальними поліцейськими. Облік таких осіб не обов'язково має супроводжуватися веденням оперативно-профілактичних справ. Головна мета такого обліку - інформування ювенального інспектора про перебування таких осіб на території його обслуговування та проведення з підобліковими особами превентивних заходів.

Аналіз чинного законодавства дозволяє акцентувати на тому, що ювенальний поліцейський несе юридичну відповідальність за невиконання покладених службових обов'язків на загальних підставах згідно Закону України «Про Національну поліцію». Так, відповідно до ст. 19 зазначеного нормативно-правового акту «Види відповідальності поліцейських» у разі вчинення протиправних діянь поліцейські несуть кримінальну, адміністративну, цивільно-правову та дисциплінарну відповідальність відповідно до закону. Отже, можна сказати, що в даній частині адміністративно-правовий статус ювенального поліцейського відповідає адміністративно-правовому статусу поліцейського взагалі.

Висновки. Підсумовуючи викладене, ми пропонуємо під адміністративно-правовим статусом ювенального поліцейського розуміти регламентовану нормативно-правовими актами України сукупність прав та обов'язків щодо запобігання вчиненню дітьми та щодо дітей кримінальних і адміністративних правопорушень, виявлення причин і умов, які цьому сприяють, вжиття в межах своєї компетенції заходів для їх усунення, а також юридичну відповідальність у разі невиконання покладених обов'язків.

Ми вбачаємо такі напрямки подальшого удосконалення адміністративно-правового статусу ювенального поліцейського, які потребують додаткового наукового дослідження та обґрунтування:

доповнення професійно-кваліфікаційні вимоги до ювенальних поліцейських бажаною наявністю разом із юридичною ще педагогічної або психологічної освіти (фаху);

доповнення повноважень ювенального поліцейського оперативно-розшуковою функцією, яка зокрема сприятиме реалізації завдання щодо установлення місцезнаходження дитини в разі їі безвісного зникнення, та кримінально-процесуальною, яка фактично виконується під час залучення ювенальних інспекторів до участі в досудовому розслідуванні та під час судового розгляду за участю дітей;

переформатування реалізації проекту «Шкільний офіцер поліції» шляхом залучення не патрульних поліцейських, професійно-кваліфікаційні вимоги яких не відповідають наділеним повноваженням, а ювенальних поліцейських, які безпосередньо уповноважені та спеціалізуються на застосовуванні превентивних заходів відносно дітей;

доповнення повноважень ювенального поліцейського веденням обліку дорослих осіб, які вчинили адміністративні або кримінальні правопорушення щодо дитини.

\section{Література}

1. Про Національну поліцію : Закон України від 02.07.2015 р. № 580-VII. Голос України. 2015. № 141-142.

2. Про затвердження Інструкції з організації роботи підрозділів ювенальної превенції Національної поліції України : Наказ МВС України від 19.12.2017 р. № 1044. Офіційний вісник України. 2018. № 45. Стор. 116. Ст. 1589.

3. Адміністративне право України : підручник / Ю.П. Битяк, В.М. Гаращук, О.В. Дьяченко та ін.; за ред. Ю.П. Битяка. Київ : Юрінком Інтер, 2006. 544 с.

4. Адміністративне право України. Академічний курс : підручник : у 2-х т. : Т. 1. Загальна частина / ред. колегія: В.Б. Авер'янов (голова). Київ: Юридична думка, 2004. 584 c.

5. Горшенев В.М. Структура правового статуса гражданина в свете Конституции СССР 1977г. Правопорядок и правовой статус личности в развитом социалистическом обществе в свете Конституции СССР 1977 г. Cаратов : Изд-во Сарат. ун-та, 1980. С. 51-58.

6. Зуй В.В. Адміністративно-правовий статус громадян в Україні. Правова держава Україна: Проблеми, перспективи розвитку: Короткі тези доп. та наук. повід. респ. н-пр. конфер. 9-11 листопада 1995. Харків, 1995. C. 107-108.

7. Сімейний кодекс України від 10.01.2002 р. Голос України. 2002. № 38.

8. Про затвердження Інструкції з організації діяльності дільничних офіцерів поліції : Наказ МВС України від 28.07.2017 р. № 650. Офіційний вісник України. 2017. № 70. Стор. 471. Ст. 2136.

9. Про апробацію експериментальної моделі співпраці навчальних закладів і поліції «Шкільний офіцер поліції» : лист МОН від 27.05.2016 р. № 2/2-14-966-16.

Зеленський $\epsilon$. С., викладач кафедри тактико-спеціальної підготовки Дніпропетровського державного університету внутрішніх справ 